\title{
TWO-STROKE ENGINE BEHAVIOR (SMALL CHAINSAW) OPERATING WITH NON-COMMERCIAL FUEL BLENDS AND DIVERSE LUBRICATION
}

\author{
R. L. da Silva ${ }^{a}$, \\ M. M. Vieirab, \\ and S. X. de Brito $\mathrm{Jr}^{\mathrm{a}}$ \\ ${ }^{a}$ Universidade Federal da Grande Dourados \\ Engenharia Mecânica \& Engenharia de Energia \\ / Faculdade de Engenharia - UFGD \\ Rodovia MS-270, km 12 \\ CEP 79.804-970 \\ Dourados, Mato Grosso do Sul, Brasil \\ robsonsilva@ufgd.edu.br \\ ${ }^{\mathrm{b}}$ Universidade Federal de Mato Grosso \\ Engenharia Mecânica / ICAT - UFMT \\ Rodovia MT-270, km 06 \\ CEP 78.735-901 \\ Rondonópolis, Mato Grosso, Brasil \\ mmendes@ufmt.br \\ Received: September 08, 2015 \\ Revised: September 30, 2015 \\ Accepted: October 23, 2015
}

\section{ABSTRACT}

The paper presents results for experimental tests in a two-stroke internal combustions engine operating on commercial fuel (gasoline and ethanol blends), with different proportions in mineral oil for lubrication purposes. Appropriate instrumentation was used to carry out the measurement of the quantities of interest, namely fuel consumption (g/s), angular velocity (rpm) and emissions (CO2 and NOx). The methodology was based on regulations from INMETRO (motor vehicles energy conversion efficiency) and ABNT (testing of internal combustion engines). Results obtained are analyzed and discussed for the fuel consumption versus angular velocity $(\mathrm{g} / \mathrm{s} \mathrm{x} \mathrm{rpm)} \mathrm{for}$ each combination fuel blend and lubricating oil (quantities). Main findings are that fuel consumption increases non linearly as angular velocity increases and as lubrication lowers, while emissions decreases as angular velocity increases. Lowest fuel consumption and emissions occurred, respectively, for A25/L1:25 and A25/L1:50 (commercial fuel and standard lubrication)

Keywords: internal combustion engines, liquid biofuels (ethanol), emissions, lubricant oil

\section{NOMENCLATURE}

A ethanol volume fraction, $\mathrm{mL}$ (see Fig. 2)

ANP Petroleum, Natural Gas and Biofuels National Agency

API American Petroleum Institute

C fuel mass flow or fuel consumption, $\mathrm{g} / \mathrm{s}$

D differences in two fuel consumption tests, \%

E fuel blend indication, \%

EAR anhydrous ethanol fuel

EHR hydrous ethanol fuel

L lubrication ratio, \%

$\mathrm{m}$ mass registered in tests by balance, $\mathrm{g}$

n angular velocity, rpm

ppm particles per million

$\mathrm{R}$ experimental data fitting quality

rev revolutions (unitary full turn)

rpm rotation per minute or revolutions/min

$\mathrm{T}$ temperature, ${ }^{\circ} \mathrm{C}$

$\mathrm{t}$ time registered in tests by chronometer, $\mathrm{s}$

TC certification for two-stroke oils

$\mathrm{u}_{\mathrm{a}} \quad$ uncertainty of quantity "a"

$\mathrm{v} \quad$ volume, $\mathrm{m}^{3}$

$\mathrm{w}$ weight, $\mathrm{kg}$

\section{Greek symbols}

$v \quad$ fluid kinematic viscosity, $\mathrm{mm}^{2} / \mathrm{s}$

$\rho \quad$ fluid specific mass (or density), $\mathrm{kg} / \mathrm{m}^{3}$

$\tau \quad$ EAR volume in fuel blend, \%

\author{
Subscripts \\ 1 or " refers to test data, first set of results \\ 2 or " refers to test data, second set of results \\ final refers to final fuel tank mass measured \\ initial refers to initial fuel tank mass measured \\ $\mathrm{n} \quad$ refers to angular velocity \\ $\Delta \mathrm{m} \quad$ refers to fuel mass consumption \\ $\Delta \mathrm{t} \quad$ refers to time elapsed in tests \\ Lab refers for laboratory environmental conditions
}

\section{INTRODUCTION}

Two-stroke internal combustion engines stand out by mechanical simplicity compared to four-stroke engines. Therefore, they are practical handling equipment since they have lower power-weight ratio and are more compact than four-stroke ones. Commercial two-stroke engines are available coupled 
with tools or equipment for maintenance purposes, as for example: chainsaws for cutting and pruning of branches and trees, lawn mowers, leaf blowers, water pumps, etc. Often, they are portable and thus maintain certain closeness to the user, which implies possible exhaust gases and/or particles from the exhaust system, during it whole operation. Given the large number of applications for small two-stroke engines, changes in the commercial fuel (intensification of biofuels as ethanol) and lubrication mixing can improve its performance in terms of energy conversion efficiency, minimize gas emissions, among other benefits as life span increases in the engine components and the machine as a whole.

In

September

2014

(http://www.valor.com.br/empresas/3709986/dilmasanciona-lei-que-permite-mais-etanol-na-mistura-

com-gasolina, acessed on 15 September, 2014) Brazilian government has authorized an increase from $25.0 \%$ up to $27.5 \%$ for the ethanol in commercial gasoline, that is, a fuel blend of ethanol (27.5\%) and gasoline (72.5\%). Even if it is not mandatory for the ANP - National Agency for Petroleum, Natural Gas and Biofuels, a BR Distributor (Petrobras subsidiary), sold 535 thousand liters of that maximum ethanol fuel blend to vehicle manufactures (Volkswagen and Hyundai) to this companies make some researches, with this increase of ethanol. Commercial gasoline fuel, until then, presents $25 \%$ ethanol in its composition, and in November 2006 it was 23\%.

The use of commercial fuel blends, as gasoline and ethanol, in Otto Cycle combustion engines is extensively explored in four-stroke configuration, considering that this feature is already being used in Brazil since the 70s. For success, countries like the United States have also adopted the measure in 2010 and increased from $10 \%$ up to $15 \%$, the ethanol volume fraction in their commercial gasoline (http://www.unica.com.br/noticia/202557639203384 19546/aprovacao-de-maior-mistura-de-etanol-nagasolina-nos-eua-nao-significa-aumento-nasexportacoes-brasileiras/, accessed on 10 February, 2014).

Authors consider that the research on how fuel samples considering ethanol addition or reduction in commercial gasoline in two-stroke engine performance analysis is something that should be looked for. Results can bring about advantages such as those observed in four-stroke engines by Gravalos et al (2013), that indicated lower CO and higher CO2 and NO emissions when gasoline/ethanol fuel blends increases from $2 \%$ up to $22 \%$. Kumar et al (2012) offer advantageous data on the levels of emissions, when having $20 \%$ alcohol and $80 \%$ gasoline in fuel in a 2 stroke engine, with respect to pure gasoline. Thermal efficiency also improved in their study.

Albuquerque et al (2011) point out that synthetic lubricating oils, when compared to mineral lubricant oils, minimize hydrocarbons emissions ("non-burned" fuel) in exhaust gases at internal combustion engines. In two-stroke engines, lubricating oil is mixed directly in the fuel in a manufacturer's predetermined proportion. When that lubrication proportionality is out of the specified, it can result in fuel wastage, reduced performance, combustion deficiency, or even compromising the engine moving and static parts life cycle. Wang and Lee (1997) developed an electrochemical sensor to verify the oils type that is used in engines.

\section{METHODOLOGY}

A typical four-row tube and plate A onecylinder, two-stroke, $0.25 \mathrm{~L}\left(250 \mathrm{~cm}^{3}\right)$, gasoline fuel, spark ignition (Otto Cycle) engine was used in the tests. Additional technical data are: displacement 30,1 cm³; Cylinder diameter - $37 \mathrm{~mm}$; Piston stroke $28 \mathrm{~mm}$; Power $1.3 \mathrm{~kW}$ at $8500 \mathrm{rev} / \mathrm{min} ; 2.800$ $\mathrm{rev} / \mathrm{min}$ and $14.000 \mathrm{rev} / \mathrm{min}$ when in idle speed and maximum speed, respectively; Weigh - 3.9 kg; Power-weight ratio - $3.0 \mathrm{~kg} / \mathrm{kW}$. Ignition system is through magnetic ignition with electronic control. Fuel system works with membrane carburetor insensitive to the working position, with an integrated fuel pump. Torque information was not available in technical data from manufacturer's manual (http://www.stihl.com.br/Produtos-

STIHL/Motosserras/Motosserras-para-usodom\%C3\%A9stico/2212-1524/Motosserra-MS170.aspx $>$, acessed on 15 Setember, 2014), and also it was not obtained in the present work.

Technical standards considered were for NBR 6396 (ABNT, 1976), which applies to reciprocating internal combustion engines in non-vehicular applications, when acquiring data in the present work (fuel consumption and angular speeds). Tests were carried out in UFGD/FAEN Energy Engineering facilities. The two-stroke engine was operated with commercial and non-commercial fuel blends (gasoline and ethanol), after uncoupling the saw and its fuel tank, which was positioned in a balance to fuel mass registration. The engine was originally coupled in a small chainsaw (manufacturer: STIHL, model: MS 170), as pointed out in Fig. (1).

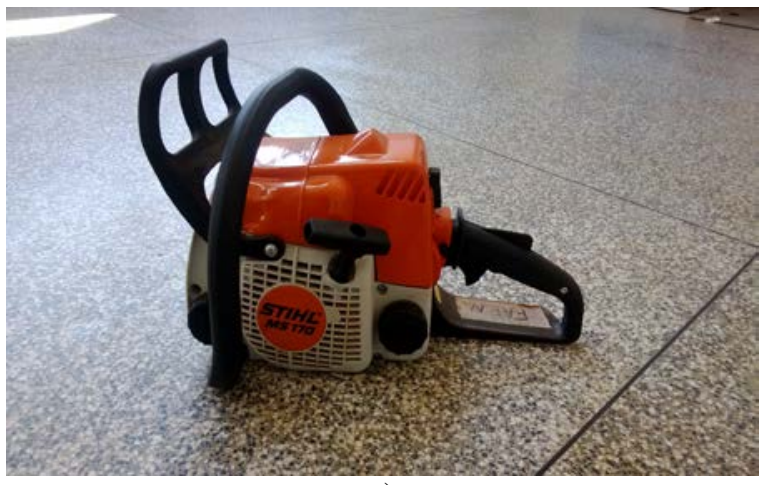

a) 


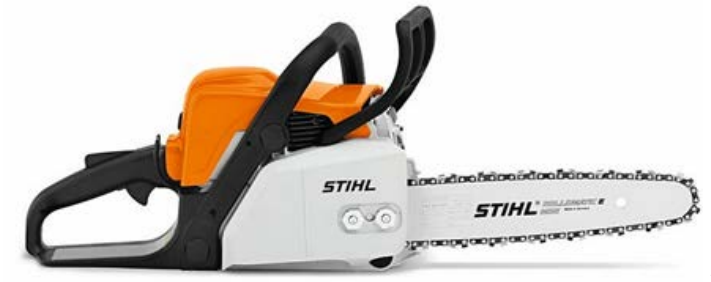

b)

Figure 1. Two-stroke engine used in tests at UFGD

(a); Chainsaw at the equipment's manual (b).

\section{Fuel and lubrication samples}

Fuel samples used in consumption measurement during tests were prepared according to standard requirements, as: NBR 13992 (ABNT, 2008), NBR 8689, NBR 13993 (ABNT, 2008, 2012 and 2013, respectively). According to definitions and terminologies, "EAR" is anhydrous ethanol reference fuel (or "AEAC”, anhydrous ethyl alcohol reference fuel) and "Gasool / Gasohol" is a fuel predominantly composed gasoline, also containing a percentage of "EAR" / "AEAC" and EHR is hydrous ethanol fuel. Then specification AxHy is for a vehicle fuel composed by " $x$ " \% of EAR and " $y$ " \% of EHR, as indicated in NBR 8689 (ABNT, 2012).

$$
\tau=[2 .(\mathrm{A}-50)]+1
$$

To determine the AEAC volume fraction in commercial Gasohol, samples were evaluated in accordance to NBR 13992 (ABNT, 2008). The original Gasohol is separated by using a $100 \mathrm{~mL}$ glass beaker. A fraction of gasoline (100\% pure) remains in the top layer and, in the lower layer remains a mixture volume, A $(\mathrm{mL})$, consisting of ethanol reference fuel (EAR) and aqueous solution of sodium chloride $(\mathrm{NaCl})$ at $10 \% \mathrm{w} / \mathrm{v}\left(\mathrm{kg} / \mathrm{m}^{3}\right)$. Then, EAR volume percentage, $\tau(\%)$, is calculated by Equation (1), as pointed out in NBR 13992 (ABNT, 2008). This determination is shown in Figure 2, for $\tau=25 \%$ and $\mathrm{A}=62.5 \mathrm{~mL}$. Then, commercial fuel samples in the tests were identified as gasohol A25 (25\% EAR and 0\% EHR), confirming that fuel purchased at a refueling point in Dourados-MS was under ANP standards at that time.

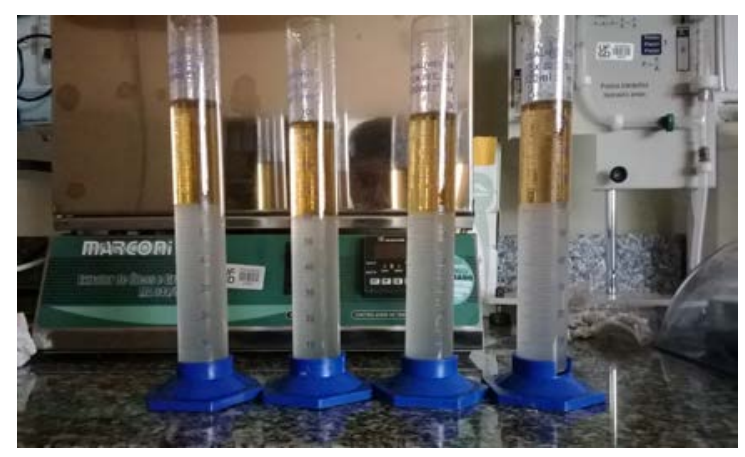

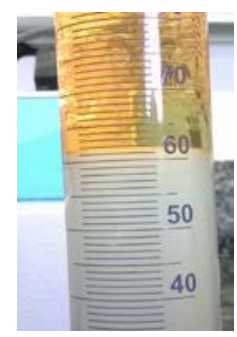

Figure 2. Commercial Gasohol samples for EAC volume fraction confirmation, UFGD facilities (2014).

Fuel samples with three diverse levels of lubrication oil were considered in this work: L1:25, L1:50 and L1:100. The second one corresponds to the standard recommendation, according to the chainsaw manual. First and third ones are, respectively, half and double the recommended fraction of lubrication oil. These fuel samples are identified in the results obtained as: A25/L1:25, A25/L1:50 and A25/L1:100.

The basic purpose of lubricant oil in a two stroke engine is to guarantee components lubrication and engine cleaning. Chainsaw manufacturer also indicates that, if using another oil brand, consider mixing ratio of $\mathrm{L} 1: 25$ and de-carbonization after operating $300 \mathrm{~h}$, instead of recommended lubricant oil (STIHL $8017 \mathrm{H}$ ) with mixing ratio of L1:50 and de-carbonization after operating $600 \mathrm{~h}$. Lubricating oil tested has its technical specifications specified in Table 1.

Table 1. Lubricating oil specification for MS 170 chainsaw model.

\begin{tabular}{|l|r|}
\hline $\begin{array}{l}\text { STIHL } 8017 \quad \mathrm{H} \mathrm{(air-cooled} \\
\text { engine), developed by Castrol }\end{array}$ & E25 L1:50 \\
\hline Base & Mineral \\
\hline Specification (ANP 0208) & API TC SAE 30 \\
\hline $\begin{array}{l}\rho\left(\mathrm{kg} / \mathrm{m}^{3}\right), \\
\left.\text { specific mass (at } 15^{\circ} \mathrm{C}\right)\end{array}$ & 882.1 \\
\hline $\begin{array}{l}v=\mu / \rho\left(\mathrm{mm}^{2} / \mathrm{s}\right), \text { fluid kinematic } \\
\text { viscosity, at } 40^{\circ} \mathrm{C}\end{array}$ & 101.00 \\
\hline$v$, at $100^{\circ} \mathrm{C}$ & 11.72 \\
\hline
\end{tabular}

\section{Ambient conditions and instrumentation}

Table 2 shows the average values for ambient conditions registered at the UFGD facilities when tests were performed. All tests were under requirements range, according to NBR 7024 (ABNT, 2010), except for a single one that was conducted at $\mathrm{T}=30.7^{\circ} \mathrm{C}$, while recommended values are $\mathrm{T}_{\mathrm{Lab}}=$ $(25 \pm 5)^{\circ} \mathrm{C}$. Measuring instruments and its technical specifications are available Table 3. Laboratory ambient conditions were registered manually.

Table 2. Laboratory conditions in tests.

\begin{tabular}{|l|c|c|c|}
\hline & E25 & E25 & E25 \\
Blend (E) and Lubrication ratio (L) & L1:50 & L1:25 & L1:100 \\
\hline Temperature $\left({ }^{\circ} \mathrm{C}\right)$ & 28.2 & 30.7 & 29.9 \\
\hline Relative Humidity (\%) & 69 & 51 & 57 \\
\hline Barometric Pressure $\left(\mathrm{hPa}=10^{2} \mathrm{~Pa}\right)$ & 958.5 & 956.5 & 957.5 \\
\hline
\end{tabular}



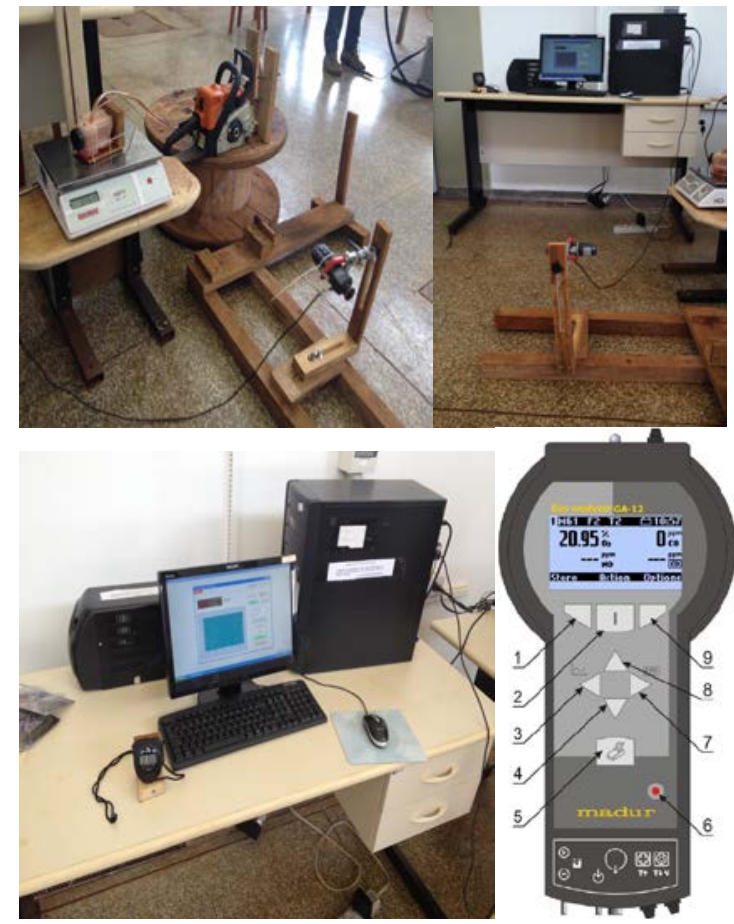

Figure 3. Experimental apparatus at UFGD facilities and, at right, portable gas analyzer.

Table 3. Measurements instruments technical specification.

\begin{tabular}{|c|c|c|c|c|}
\hline \begin{tabular}{|l|} 
Instrument \\
(Manufacturer, \\
Model)
\end{tabular} & Measurement & Range & Resolution & Accuracy \\
\hline $\begin{array}{l}\text { Thermo-Hygrometer- } \\
\text { Anemometer- } \\
\text { Barometer } \\
\text { (Instrutherm, THAB- } \\
500 \text { ) }\end{array}$ & $\begin{array}{l}\text { Barometric } \\
\text { pressure }\end{array}$ & $\begin{array}{c}10.0- \\
999.9 \mathrm{hPa}\end{array}$ & $\begin{array}{l}0.1 \mathrm{hPa} \\
(10 \mathrm{~Pa})\end{array}$ & $\begin{array}{l}1.5 \mathrm{hPa} \\
(150 \mathrm{~Pa})\end{array}$ \\
\hline $\begin{array}{l}\text { Tachometer } \\
\text { (Instrutherm, TDR- } \\
100)\end{array}$ & $\begin{array}{l}\text { Angular } \\
\text { velocity }\end{array}$ & \begin{tabular}{|c|}
$0.5-$ \\
19.999 \\
RPM \\
\end{tabular} & $\begin{array}{l}0.1< \\
1,000 \\
\text { RPM }\end{array}$ & $\begin{array}{l} \pm 0.1 \% \\
\text { or } \\
+1 \text { digit } \\
\end{array}$ \\
\hline $\begin{array}{l}\text { Balance } \\
\text { (Balmak, ELP-10) }\end{array}$ & Mass & \begin{tabular}{|c|} 
Max: $5 \mathrm{~kg} /$ \\
$10 \mathrm{~kg}$
\end{tabular} & $1 \mathrm{~g}$ & $1 \mathrm{~g} / 2 \mathrm{~g}$ \\
\hline $\begin{array}{l}\text { Thermo-hygrometer } \\
\text { (Instrutherm, HT- } \\
\text { 200) }\end{array}$ & \begin{tabular}{c|} 
Temperature \\
and \\
Humidity
\end{tabular} & \begin{tabular}{|c|}
$-20^{\circ} \mathrm{C}$ up \\
to $70^{\circ} \mathrm{C} /$ \\
$20 \%$ up to \\
$99 \%$
\end{tabular} & $\begin{array}{l}0.1^{\circ} \mathrm{C} / \\
1 \% \mathrm{RU}\end{array}$ & $\begin{array}{l} \pm 1^{\circ} \mathrm{C} / \\
\pm 5 \% \mathrm{RU}\end{array}$ \\
\hline $\begin{array}{l}\text { Chronometer } \\
\text { (Instrutherm, CD- } \\
2800)\end{array}$ & Time & 23h59'59" & $1 / 100 ”$ & $1 / 200 "$ \\
\hline \begin{tabular}{|l} 
Data acquisition \\
software\&cable \\
(Instrutherm, \\
SW-U801 / SW20) \\
\end{tabular} & - & - & - & - \\
\hline $\begin{array}{l}\text { Gas analyzer } \\
\text { (Madur, GA-12) }\end{array}$ & $\begin{array}{l}\text { Emissions } \\
\text { (CO2 } \\
\text { and NOx) }\end{array}$ & $\begin{array}{l}\sim 4000 \\
\text { ppm }\end{array}$ & $1 \mathrm{ppm}$ & $\pm 1 \mathrm{ppm}$ \\
\hline
\end{tabular}

\section{Experimental procedure for data acquisition}

\section{General procedure}

The minimum time to ensure the stabilization condition (steady state) was set at $10 \mathrm{~min}$, for the two-stroke engine in this work. Since with this time can be observe a steady of operation, and there was the risk of prolonged use (risk of overheating and wear parts). Although the NBR 7024 (ABNT, 2010) also establishes the prior operation of $30 \mathrm{~min}$ to ensure the condition of stabilization in automotive vehicles.

Requirements and other information of interest described in NBR 6396 (ABNT, 1976), applicable to internal combustion alternative engines not vehicular, cycle 2 times were considered, such as the chainsaw, Fig (1). Authors identified additional standards for tests, but could not have it available, as ISO 7293:1997 - Forestry machinery - Portable chain saws - Engine performance and fuel consumption (http://www.iso.org/iso/catalogue_detail.htm?csnumb er=25973, acessed on 15 Setember, 2014) that applies to engine performance and fuel consumption of forestry machinery. Future works will look for acquisition of that standard.

Measurements were performed in the engine speed range from idle up to maximum speed (wide open throttle valve), i.e., $2800 \mathrm{rev} / \mathrm{min}$ up to 14.000 $\mathrm{rev} / \mathrm{min}$, with steps of $\Delta 1000-2000 \mathrm{rev} / \mathrm{min}$. The engine angular velocity was varied trough the trigger positioning, with no load applied. Results for fuel consumption shown in this work are the average of two tests (duplicate) performed for each angular velocity, i.e., trigger positioning. Lubricating oil was

Then, for each fuel sample, 5 to 7 different angular velocities (rpm) and fuel mass flow (g/s) were obtained.

The experimental apparatus and measurement instruments are shown in Fig (3).

\section{Measurements for fuel consumption and angular velocity}

Fuel consumption measurements were performed considering the gravimetric method, NBR 7024 (ABNT, 2010), with small adaptations, i.e., fuel tank was positioned in the balance device and indicated values recorded manually.

The fuel tank is positioned in the balance, tachometer into a $0.5 \mathrm{~m}$ (minimum distance, tachometer's manual). A desktop computer with data acquisition software was used for angular velocity, $n$ (rpm). The tests were performed in duplicate by the following procedure: record the fuel tank mass every 30 seconds during 2 minutes (120 s), and angular velocity each $1 \mathrm{~s}$.

$$
\mathrm{C}=(\Delta \mathrm{m} / \Delta \mathrm{t})
$$

and its respective uncertainty given by

$$
\begin{gathered}
\mathrm{u}_{\mathrm{C}}=\sqrt{\left(\mathrm{u}_{\Delta \mathrm{m}} \cdot 1 / \Delta \mathrm{t}\right)^{2}+\left(\mathrm{u}_{\Delta \mathrm{t}} \cdot-\Delta \mathrm{m} / \Delta \mathrm{t}^{2}\right)^{2}} \\
\mathrm{D}=\left[\left(\mathrm{C}_{1}-\mathrm{C}_{2}\right) / \mathrm{C}_{1}\right] \times 100 \%
\end{gathered}
$$

The fuel consumption (g/s) was determined by the Equation (2). Discrepancies were also determined, for $\mathrm{D}<5 \%$ test results are acceptable according to NBR 7024 (ABNT, 2010), otherwise it 
is required to repeat the procedure until a valid pair of results is obtained. Equation (3) shows the model for calculating discrepancy (\%) for two sets of fuel consumption, or fuel mass flow (g/s).

Where $\Delta \mathrm{m}=\mathrm{m}_{\text {final }}$ (g) and minitial (g), respectively, final and initial fuel tank mass measured. C1 (g/s) and C2 (g/s) are the fuel consumption in tests, first and second (duplicate) respectively, and D (\%) is the discrepancy between them. Uncertainties, from Table 3, are: $\mathrm{u} \Delta \mathrm{m}= \pm 1 \mathrm{~g}, \mathrm{u} \Delta \mathrm{t}_{\mathrm{t}}$ $= \pm 0.005 \mathrm{~s}$ and $\mathrm{un}_{\mathrm{n}}= \pm 1 \mathrm{rpm}$.

\section{EXPERIMENTAL RESULTS \& DISCUSSIONS}

Results for fuel consumption versus angular velocity, C (g/s) x n (RPM), are available in Fig. 4. There is a general behavior of increasing " $\mathrm{C}$ " when increasing " $n$ ", except when lubrication is higher than recommended by manufactures, i.e., A25/L1:25 and then it is occurs a minimum " $\mathrm{C}$ " around $5000 \mathrm{rpm}$ and not in idle speed ( 2000 rpm). Authors believe this is through the additional calorific value in the fuel sample overly lubricated, twice the recommended values, i.e., additional chemical energy is converted to thermal and then mechanical energy inside the engine combustion chamber. Lubricating oils for energy conversion is an interesting possibility, as indicated by Cerqueira (2004).

It is also worth notice that for fuel samples A25/L1:25 and A25/L1:50, experimental results (always in duplicate and $\mathrm{D} \leq 5 \%$ ) are well fit at the empirical equations $\left(\mathrm{R}^{2}>90 \%\right)$, better than A25/L1:100 and slightly better than A20/L1:50. Only a few experimental results for A20/L1:50 were usable, since other results were compromised due to scuffing damages (BRUNETTI, 2012) occurred in engine after tests on low lubrication (A25/L1:100) and authors could not obtain, at that moment, a complete set of experimental results.
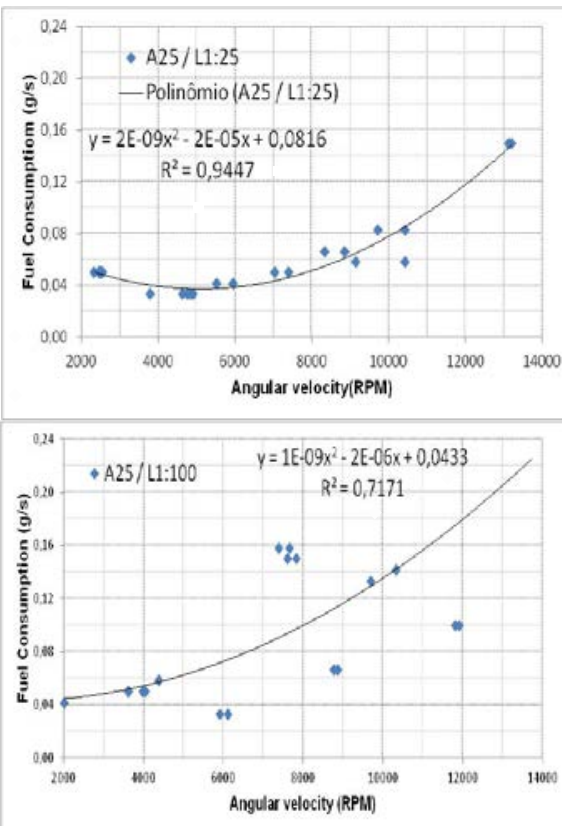

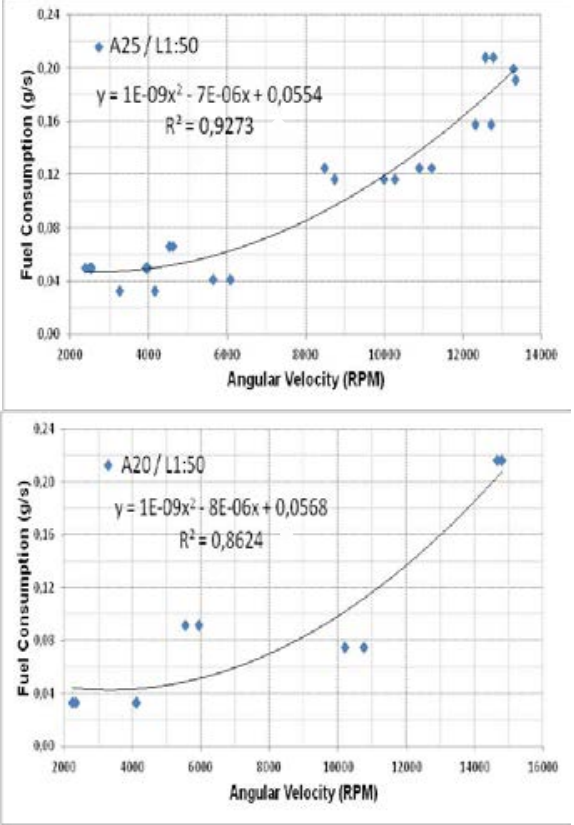

Figure 4. Fuel consumption at four fuel/lubrication samples - A25/L1:25, A25/L1:100, A25/L1:50 and A20/L1:50.

As for uncertainties, angular velocity values were obtained from direct measurements, then $\mathrm{un}_{\mathrm{n}}=$ $\pm 1 \mathrm{rpm}$ (Table 3, tachometer). Uncertainties for fuel mass flow are mainly dependent from $\mathrm{u}_{\Delta \mathrm{t}}=0.005 \mathrm{~s}$, while both minimum and maximum absolute standard uncertainties are $\pm 0.008 \mathrm{~g} / \mathrm{s}$. However, for relative standard uncertainties, minimum and maximum values are, respectively, $3 \%$ and $25 \%$ (worst conditions for minimum fuel mass consumption).

Table 4. Experimental uncertainties, C(g/s) @n(rpm).

\begin{tabular}{|l|r|r|r|r|}
\hline $\begin{array}{l}\text { Extreme } \\
\text { conditions } \\
\text { identified }\end{array}$ & A25/L1:25 & A25/L1:100 & A25/L1:50 & A20/L1:50 \\
\hline $\begin{array}{l}\text { Maximum } \\
\text { "C" \& }\end{array}$ & $0.150 \pm 6 \%$ & $0.250 \pm 3 \%$ & $0.208 \pm 4 \%$ & $0.217 \pm 4 \%$ \\
$\begin{array}{l}\text { Minimum } \\
\text { relative } \\
\text { standard } \\
\text { uncertainty }\end{array}$ & $\sim 13156$ & $\sim 13577$ & $\sim 12653$ & $\sim 14722$ \\
$\mathrm{rpm}$ & $\mathrm{rpm}$ & $\mathrm{rpm}$ & $\mathrm{rpm}$ \\
\hline $\begin{array}{l}\text { Minimum } \\
\text { "C" \& }\end{array}$ & $0.033 \pm 25 \%$ & $0.033 \pm 25 \%$ & $0.033 \pm 25 \%$ & $0.033 \pm 25 \%$ \\
$\begin{array}{l}\text { Maximum } \\
\text { relative } \\
\text { standard } \\
\text { uncertainty }\end{array}$ & $\sim 4489 \mathrm{rpm}$ & $\sim 6006 \mathrm{rpm}$ & $\sim 3699 \mathrm{rpm}$ & $\sim 2872 \mathrm{rpm}$ \\
\hline
\end{tabular}

In Figure 5, throttle trigger position was held fixed and angular speed was registered during tests (2 minutes for each one) and refer to A20/L1:50 fuel sample which were still consistent to other fuel consumption. As authors pointed out previously, these results were obtained just after A25/L1:100 tests (lower oil lubrication). Angular velocity behavior presents several inverted peak points, what is consistent to the engine behavior at the scuffing condition originated mainly due to low oil lubricant quantities as shown by Brunetti (2012). These peaks 
do appear at angular velocity levels of 14000-15000 rpm, and authors believe that is due to the quick reciprocating movement between piston and cylinder.

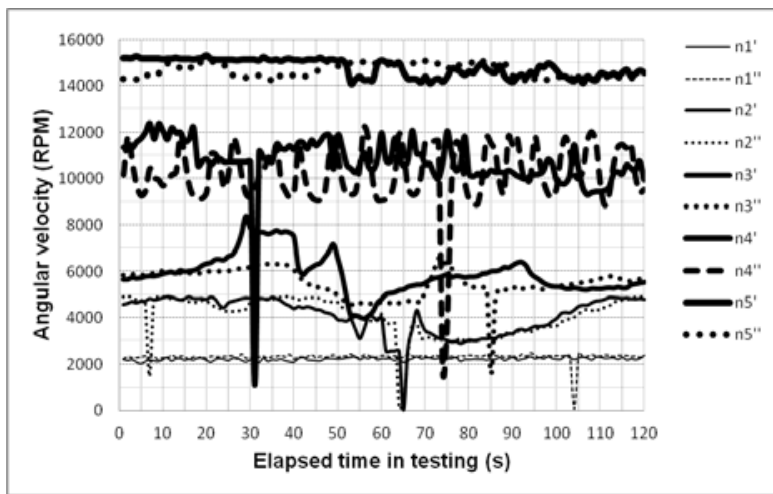

Figure 5. Angular velocity (rpm) behavior during tests for A20/L1:50.

Those inverted peak points occurred only during few second during two minutes tests and no sudden power shutdown occurred during these data acquisition. Then, authors are considering that mean values for angular velocities are presented in Table 5 , and they are still reasonable values to be matched with fuel consumption in results previously presented in Figure 4.

Table 5. Angular velocity mean values, n (rpm).

\begin{tabular}{|l|c|c|c|c|c|}
\hline $\begin{array}{c}\text { Angular velocity } \\
\text { (rpm) }\end{array}$ & $\mathrm{n} 1$ & $\mathrm{n} 2$ & $\mathrm{n} 3$ & $\mathrm{n} 4$ & $\mathrm{n} 5$ \\
\hline $\begin{array}{l}\text { n', } 1^{\text {st }} \text { set of results } \\
\text { (mean value) }\end{array}$ & 2225 & 4079 & 5917 & 10741 & 14791 \\
\hline $\begin{array}{l}\text { n', 2nd } \text { set of results } \\
\text { (mean value) }\end{array}$ & 2311 & 4096 & 5520 & 10197 & 14654 \\
\hline $\begin{array}{l}\text { n (mean value from } \\
\text { both duplicate results) }\end{array}$ & 2268 & 4088 & 5719 & 10469 & 14723 \\
\hline
\end{tabular}

Then, once the results obtained were previously analyzed and discussed, empirical equations representing the fuel consumption behavior as angular velocity varies are gathered in Figure 6. For all fuel samples, maximum " $\mathrm{C}$ " occurs for maximum angular velocity, around 13.000-14.000 rpm, and its values increases in the following order: $\sim 0,15 \mathrm{~g} / \mathrm{s}$ for A25/L1:25; 0,19 g/s for A25/L1:50; 0,19 g/s for A20/L1:50; 0,20 g/s for A25/L1:100. That behavior indicates that, as the proportion of lubrication oil contained in the fuel sample decreases, it implies in higher fuel consumption that will result in lowering the engine efficiency, what is in accordance to results obtained by Wang and Lee (1997). Maximum fuel consumption stayed quite the same for different EAR proportion in the Gasohol, when comparing "C $\mathrm{C}$ " for A25/L1:50 and A20/L1:50, 0,19 g/s, in both conditions.

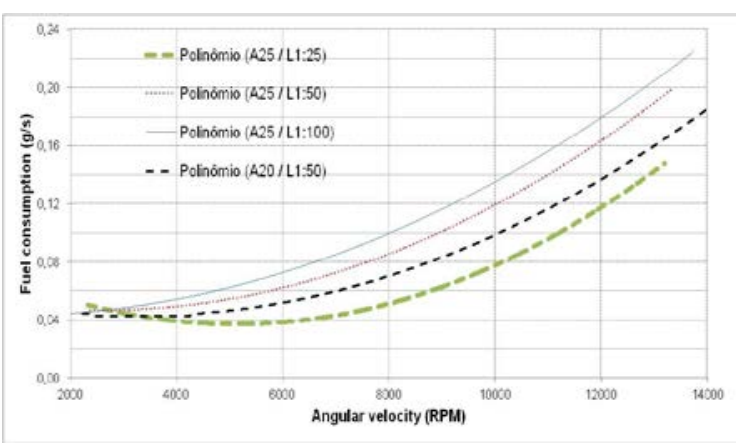

Figure 6. Empirical equations representing fuel consumption behavior at tests in this work.

Figure 7 shows results for the two-stroke engine emissions, CO2 and NOx. Authors would like to point out that GA-12 gas analyzer measuring range reached $\sim 4000 \mathrm{ppm}$, and the two stroke engine (chainsaw) exceeded that limit. Then, in order to obtain at least a qualitative behavior, the gas analyzer was positioned $\sim 0,15 \mathrm{~m}$ far from the exhaustion point were, after ambient air dilution, emission values were able to be registered. In that situation, quantitative values indicated in Figure 7 do not correspond to the real emission just after engine exhaustion. Thus, the behavior is as follows: $\mathrm{CO} 2$ and NOx emissions decrease as angular speed increases for all fuel samples. Higher values for $\mathrm{CO}$ emissions occur for A20/L1:50 ( 3500 ppm at $\sim 6000 \mathrm{rpm})$, the lowest ethanol quantity in the fuel sample, followed by A25/L1:100 ( 3000 ppm at $2000 \mathrm{rpm})$, the lowest lubricant oil in the fuel sample. In a similar behavior, NOx emissions are higher and for A25/L1:100 ( 35 ppm at $\sim 2000 \mathrm{rpm}$ ) and A20/L1:50 ( 15 ppm at $\sim 2000-6000 \mathrm{rpm})$. Lowest values for CO2 and NOx occurs for commercial fuel sample and standard oil lubrication mixture, A25/L1:50: CO2 emissions ( 1500 ppm at $\sim 4000 \mathrm{rpm}$ ) are at least two times lower than the worst test conditions (A25/L1:100 or A20/L1:50), while NOx emissions ( 10 ppm at $\sim 3000 \mathrm{rpm}$ ) are at least $1 / 3$ up to $2 / 3$ times lower than the worst test conditions (again, A25/L1:100 or A20/L1:50). Thus, commercial fuel and standard lubrication (A25/L1:50) showed to be the best option for emissions, probably due to air-fuel rates that were not altered during tests.

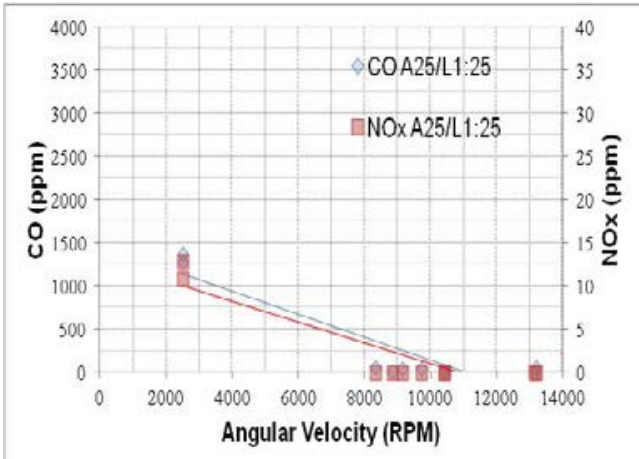



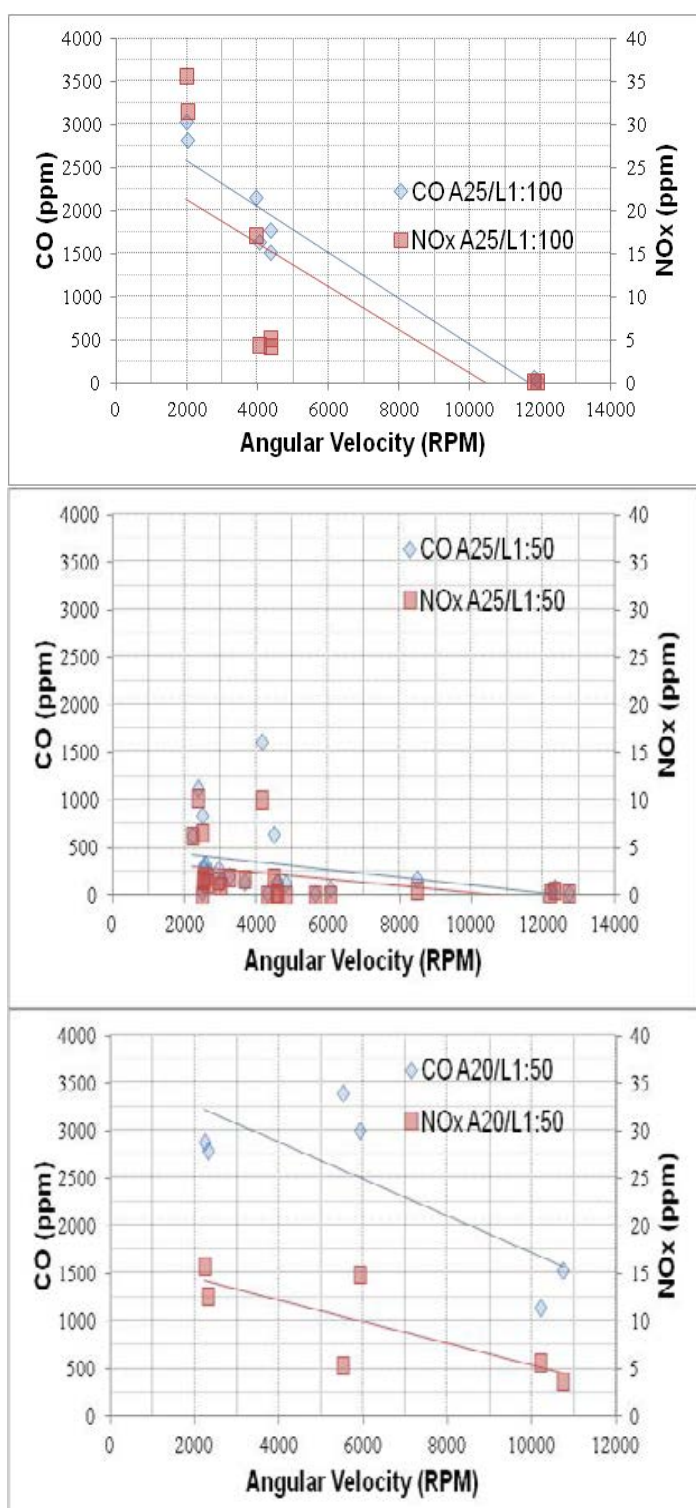

Figure 7. Qualitative results for CO and NOx emissions in the two-stroke engine tests.

\section{CONCLUSIONS}

The paper is the result of a laboratory tests on two-stroke internal combustion engine in which their performance was analyzed and compared using commercial and non-commercial fuel blends (gasoline + ethanol) and different lubrication oil mixtures. The realization of other studies with another two-stroke engine types and equipment for better measurements of new tests will be made in the future. Main findings in this work are pointed out next.

a) Fuel consumption (fuel mass flow, kg/s) increases non-linearly, as angular velocity increases. Exception occurs for higher lubrication than recommended (A25/11:25), when fuel consumption decreases for low angular velocities before start increasing as the general behavior for all other fuel/oil samples; b) Even though experimental results for A20/L1:50 were partially compromised by scuffing damage occurred at low lubrications tests, mean values for fuel consumption and angular velocity were good enough to join other fuel sample results analysis $\left(\mathrm{R}^{2}\right.$ $>86 \%$ );

c) As the proportion of lubrication oil contained in the fuel sample decreases, it implies in higher fuel consumption. It was not measured in this work, but according to the literature, that will result in lowering the engine efficiency;

d) Emissions (CO2 and NOx) qualitative behavior, for all fuel samples and lubricating oil mixing, indicated a decreasing as angular velocity increases; e) Better performance, i.e, the lowest fuel consumption occurred for fuel sample A25/L1:25 ( 5000 rpm) and the lowest emissions occurred for fuel sample A25/L1:50 (commercial fuel and standard lubrication).

\section{ACKNOWLEDGEMENTS}

Authors thank the Mato Grosso do Sul Foundation for Support to the Development of Education, Science and Technology (FUNDECT), for the financial support to this work, through research project "Motores de Combustão Interna 2 Tempos: eficiência e curvas características operando com diferentes misturas combustíveis”, grant 0262/12. Also to the UFGD/FAEN Energy Engineering facilities (Combustion, Thermal Systems and Machines Laboratory) were the experiments were carried out with the assistance also from Prof. Ramon E. P. Silva and technician José Carlos Venturin. Thanks to the scholarships for undergraduate student, scientific initiation program from granted by CAPES and CNPq. Also thank to Prof. Edmilson de Souza (UEMS) that lent the portable gas analyzer (GA-12) to obtain emissions behavior at the two-stroke engine tests.

\section{REFERENCES}

ABNT - ASSOCIAÇÃO BRASILEIRA DE NORMAS TÉCNICAS, 1976, NBR 6396: Motores Alternativos de Combustão Interna, não Veiculares, 29p. (in Portuguese)

ABNT - ASSOCIAÇÃO BRASILEIRA DE NORMAS TÉCNICAS, 2010, NBR 7024: Veículos Rodoviários Automotores Leves - Medição do Consumo de Combustível - Método de Ensaio, 13p. (in Portuguese)

ABNT - ASSOCIAÇÃO BRASILEIRA DE NORMAS TÉCNICAS, 2012, NBR 8689: Veículos Rodoviários Automotores Leves - Combustíveis para Ensaio - Requisitos, 4p. (in Portuguese)

ABNT - ASSOCIAÇÃO BRASILEIRA DE NORMAS TÉCNICAS, 2008, NBR 13992: Gasolina Automotiva - Determinação do Teor de Álcool Etílico Anidro Combustível (AEAC), 3p. (in 


\section{Portuguese)}

ABNT - ASSOCIAÇÃO BRASILEIRA DE NORMAS TÉCNICAS, 2002, NBR 13993: Álcool Etílico Combustível - Determinação do Teor de Gasolina, 2p. (in Portuguese)

Albuquerque, P. C. C., Avila, R. N. A., Zárante, P. H. B., and Sodré, J. R., 2011, Lubricating Oil Influence on Exhaust Hydrocarbon Emissions from a Gasoline Fueled Engine, Tribology International, Vol. 44, pp. 1796-1799.

Brunetti, F., 2012, Motores de Combustão Interna - Vol. 1 \& Vol. 2, Bluncher. (in Portuguese)

Cerqueira, C. P., 2004, Estudo do Reaproveitamento Energético de Óleos Lubrificantes Usados, Master Thesis, Universidade, Salvador, BA, Brasil. (in Portuguese)

Gravalos, I., Moshou, D., Gialamas, Th., Xyradakis, P., Kateris, D., and Tsiropoulos, Z., 2013, Emissions Characteristics of Spark Ignition Engine Operating on Lower-Higher Molecular Mass Alcohol Blended Gasoline Fuels, Renewable Energy, Vol. 50, pp. 27-32.

Kumar, M. V. S., Krishna, M. V. S. M., Murthy, P. V. K., Reddy, D. N., and Kishor, K., 2011, Performance of Copper Coated two Stroke Spark Ignition Engine with Gasohol with Catalytic Converter with Different Catalysts, International Journal of Applied Engineering Research, Vol. 2, No. 1, pp. 205-218.

Wang, S. S., and Lee, H. S., 1997, An Electrochemical Sensor for Distinguishing TwoStroke-Engine Oils, Sensors and Actuators Series B, Vol. 40, pp. 199-203. 